\title{
Public Health Sector Workforce in Serbia and World Economic Crisis
}

\author{
Milena Gajić-Stevanović ${ }^{1}$, Darinka Perišić-Rainicke², Snežana Dimitrijević1, \\ Nevenka Teodorović3 ${ }^{3}$ Slavoljub Živković 3 \\ IInstitut of Public Health of Serbia "Dr Milan Jovanović Batut", Belgrade, Serbia; \\ 2Schefield University, Belgrade, Serbia; \\ ${ }^{3}$ Faculty of Dental Medicine, University of Belgrade, Belgrade, Serbia
}

\begin{abstract}
SUMMARY
Introduction Health care, as one of the most important and sensitive fields of human endeavour, has a significant social impact; therefore changes in this area have wide implications on society in general. The latest economic crisis resulted in slow growth of gross domestic product (GDP), high unemployment rates, low living standards, and increased poverty across the globe. This includes decreased capacity of health system, and reduced quality and supply of health services. The aim of the study was to explore possible impact of the current world economic crisis on the public health sector workforce in Serbia.

Materials and Methods The study was conducted as retrospective analyses of the Public Health Institute (PHI) human resource data, the Republic Statistical Office publications and database, the Republic Development Bureau report, as well as the analysis of healthcare expenditures obtained from the Chamber of Health Institutions reports. The comparative analytical method was used for the assesment of socio-economic and human resource indicators over the period of five years, 2006 to 2010.

Results Results showed that the world economic crisis discontinued steady economic growth in Serbia. Between 2006 and 2008, the real GDP growth rate has been fluctuating between $3.6 \%$ and $5.4 \%$, while in 2009 it had negative growth rate of $-3.1 \%$ and slight increase in 2010 of $1.0 \%$. In 2006, the GDP per capita was US\$3,943, and by 2008 it almost doubled reaching US\$6,498, while in 2009 it fell down to US\$5,499, and continued decrease in 2010 to US\$5,006. In 2007, the overall inflation rate was $6.5 \%$, and after fluctuaion between $11.7 \%$ in 2008 and $8.4 \%$ in 2009 it droped again to $6.5 \%$ in 2010. According to the PHI, from 2006 to 2008 there was steady increase of full-time employees in the public health care sector; from 108,975 in 2006 to 114,317 in 2008. In 2009, the number of full-time employees slightly declined to 114,175 and 114,432 in 2010 . There was constant increase in total number of employees in the public health care sector, from 125,081 in 2006 to 129,357 in 2008. In 2009, the total number of employees decreased to 128,694 and in 2010 to 122,695 . At the same time, the total expenditure of human resources in the health sector as the percentage of total health expenditure declined from $37.7 \%$ in 2006 to $34.7 \%$ in 2010 . The public health sector salaries after steady increase from $59.9 \%$ of total health expenditure in 2006 to $61.2 \%$ in 2007 and 2008 , decreased to $56.2 \%$ in 2010 . The unemployment rate for medical doctors almost doubled in 2010 as compared to 2006.

Conclusion Preliminary study results showed that the world economic crisis had negative impact not only on GDP growth rate, the inflation and unemployment rate, but on the public health sector workforce, their salaries and unemployment rate in Serbia.
\end{abstract}

Keywords: workforce; public health sector; world economic crisis

\section{INTRODUCTION}

Health care, as one of the most important and sensitive fields of human endeavour, has a significant social impact; therefore changes in this area have wide implications on society in general. The latest economic crisis resulted in slow GDP growth, high unemployment rates, low living standards, and increased poverty across the globe. Lessons learned from past economic catastrophes cofirmed that crisis may harm human development in several ways including decreased capacity of health system, reduced quality and ammount of health services. Working environment as well as human, financial and technical capacities of the public health care have also been changing with the economic transition.

Socio-economic development of Serbia was affected in 2009 and 2010 by the global economic crisis, the biggest since the Great Depression in the 30-ies. However, developing position of Serbia in Europe is stable: Serbia is ranked 35th in the European development area ranking, both in terms of economic development (gross domestic product reported by the purchasing power per capita), as well as human development (Human Development Index). The influence of global economic crisis, when global economic foundations were changing inevitably resulted in non-sufficient funding of the health care 
system, specifically in Serbia, where health system is financed by compulsory health insurance contributions, based on $12.3 \%$ of payroll taxes. In the light of socio-economic changes on the global level, the socio-economic context for healthcare employees and healthcare organisations in Serbia was changed as well.

The aim of the study was to explore possible impact of the current world economic crisis on the public health sector workforce in Serbia.

\section{MATERIALS AND METHODS}

The study was conducted as retrospective analysis of the Public Health Institute (PHI) human resource data, the Republic Statistical Office (RSO) publications and database, the Republic Development Bureau (RDB) report, as well as the analysis of healthcare expenditures obtained from the Chamber of Health Institutions (CHI) reports. Comparative analytical method was used for the assesment of socio-economic and human resource indicators over the period of five years, 2006 to 2010.

\section{RESULTS}

Data showed that global economic crisis broke stable economic growth in Serbia. GDP per capita in Serbia in 2006 amounted US\$3,943 (€3,144). According to the Ministry of Finance, GDP reached US $\$ 6,498(€ 4,445)$ in 2008. In 2009 , it decreased to US\$5,499 (€ 3,955), while in 2010 continued to decline and amounted only US\$ 5,006 ( $€$ 3,781 ). In the period to 2007 , the growth rate of GDP ranged from $3.6 \%$ to $5.4 \%$ while in 2009 negative growth of $-3.1 \%$ was recorded. In $2010 \mathrm{GDP}$ had growth of a little bit over 1\% (Graph 1).

GDP per capita in Serbia, expressed through the purchasing power, was among the lowest in Europe in 2010, only 35 percentage points of the average of the European Union (Table 1). This is one percentage point decrease as compared to the previous year. According to the Human Development Index (HDI) values, Serbia occupies 60th place in the world, and 33rd in Europe. In the period from 2006 to 2010 human development in Serbia had growth for $2 \%$, life expectancy was 1 year longer, while the average and expected length of education increased slightly (Graph 2).

The report of the Ministry of Finance in 2010 introduced three new composite indexes. IHDI represents HDI adjusted on the base of inequity of distribution advances; GII index is gender inequity and the third, multidimensional poverty index (MPI) monitors household in the area of education, health and living standards. MPI index did not show significant correlation between economic development and improvement in health and education (Table 2).

In 2010 the total inflation rate was $10.3 \%$, considerably higher than in the previous year when it was $6.6 \%$. The inflation was approximately at the same level in $2008(8.6 \%)$ and 2007 (11\%) (Graph 3). The average inflation rate during the same period ranged from $6.5 \%$ in $2007,11.7 \%$ in $2008,8.4 \%$ in 2009 and $6.5 \%$ in 2010 . Comparing to the neighboring countries, Serbia had substantially higher average rate of the inflation (Table 3).

In the observed five-year period, the average real wage increased, except in 2009 and 2010 when it had downward trend (Graph 4). In 2009, the average real wage by the Ministry of Finance amounted US \$469 (€ 338), while

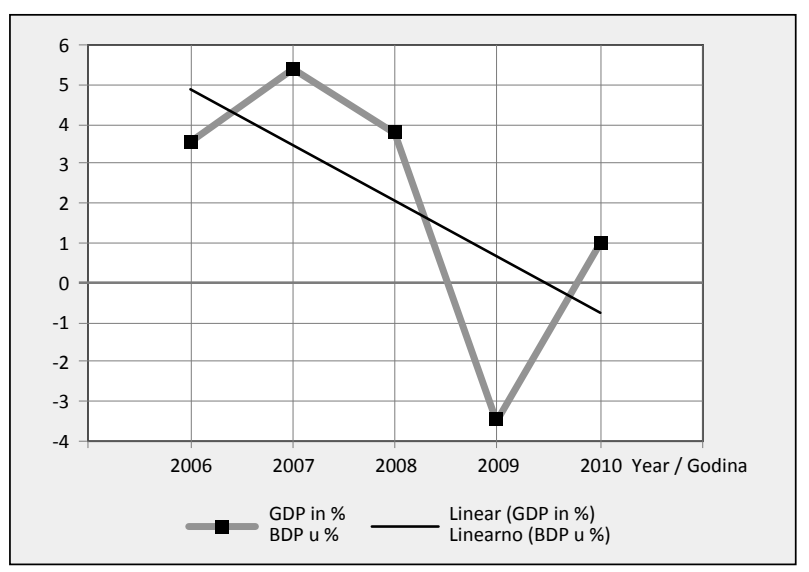

Graph 1. Growth rate of Gross domestic product (GDP) in Serbia in the period 2006-2010

Grafikon 1. Stopa rasta bruto domaćeg proizvoda (BDP) u Srbiji u periodu 2006-2010. godine

Table 1. The index of GDP per capita at purchasing power parity (PPP) in Serbia, the European Union and selected European countries in 2010 Tabela 1. Indeks BDP po kupovnoj moći po stanovniku (PPP) u Srbiji, Evropskoj Uniji i izabranim zemljama Evrope u 2010. godini

\begin{tabular}{|l|c|}
\hline $\begin{array}{l}\text { Country } \\
\text { Država }\end{array}$ & $\begin{array}{l}\text { GPD } \\
\text { BDP }\end{array}$ \\
\hline $\begin{array}{l}\text { Serbia } \\
\text { Srbija }\end{array}$ & $35 \%$ \\
\hline $\begin{array}{l}\text { Macedonia } \\
\text { Makedonija }\end{array}$ & $35 \%$ \\
\hline $\begin{array}{l}\text { Bulgaria } \\
\text { Bugarska }\end{array}$ & $44 \%$ \\
\hline $\begin{array}{l}\text { Romania } \\
\text { Rumunija }\end{array}$ & $45 \%$ \\
\hline $\begin{array}{l}\text { Croatia } \\
\text { Hrvatska }\end{array}$ & $62 \%$ \\
\hline $\begin{array}{l}\text { Hungary } \\
\text { Mađarska }\end{array}$ & $64 \%$ \\
\hline $\begin{array}{l}\text { Slovakia } \\
\text { Slovačka }\end{array}$ & $74 \%$ \\
\hline $\begin{array}{l}\text { Czech Republic } \\
\text { Češka Republika }\end{array}$ & $80 \%$ \\
\hline $\begin{array}{l}\text { Portugal } \\
\text { Portugal }\end{array}$ & $81 \%$ \\
\hline $\begin{array}{l}\text { Slovenia } \\
\text { Slovenija }\end{array}$ & $179 \%$ \\
\hline $\begin{array}{l}\text { Greece } \\
\text { Grčka }\end{array}$ & $86 \%$ \\
\hline $\begin{array}{l}\text { European Union } \\
\text { Evropska Unija }\end{array}$ & $100 \%$ \\
\hline $\begin{array}{l}\text { Belgium } \\
\text { Belgija }\end{array}$ & $89 \%$ \\
\hline $\begin{array}{l}\text { Ireland } \\
\text { Irska }\end{array}$ & \\
\hline $\begin{array}{l}\text { Norway } \\
\text { Norveška }\end{array}$ & $18 \%$ \\
\hline $\begin{array}{l}\text { Luxembourg } \\
\text { Luksemburg }\end{array}$ & \\
\hline
\end{tabular}




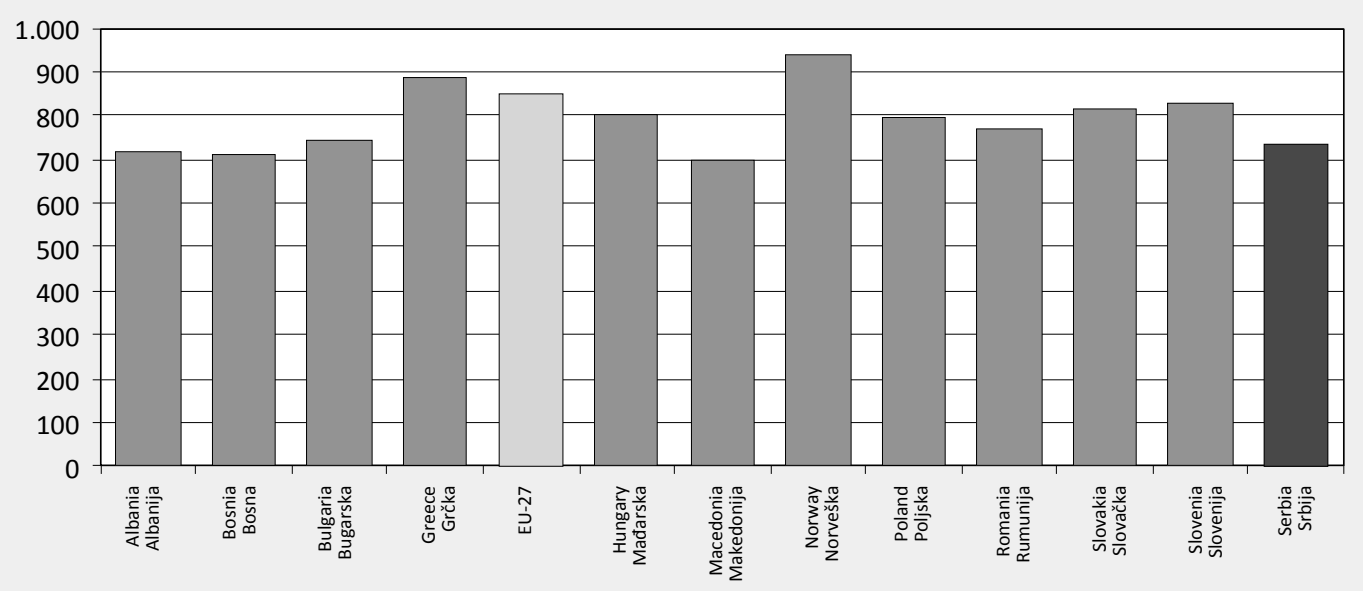

Graph 2. Human development index (HDI) in Serbia and selected European countries in 2010 Grafikon 2. Indeks ljudskog razvoja (HDI) u Srbiji i izabranim zemljama Evrope u 2010. godini

Table 2. Achievement in Serbia in terms of new indicators in 2010 Tabela 2. Dostignuća u Srbiji u pogledu novih pokazatelja 2010. godine

\begin{tabular}{|c|c|c|c|c|c|}
\hline $\begin{array}{l}\text { HDI } \\
\text { country's } \\
\text { rank } \\
\text { HDI rang } \\
\text { države }\end{array}$ & $\begin{array}{l}\text { Country } \\
\text { Država }\end{array}$ & IHDI & GII & MPI & $\begin{array}{c}\text { Gini } \\
\text { coefficient } \\
\text { Đinijev } \\
\text { koefici- } \\
\text { jent }\end{array}$ \\
\hline 29 & $\begin{array}{l}\text { Slovenia } \\
\text { Slovenija }\end{array}$ & 0.656 & 0.293 & - & 31.2 \\
\hline 36 & $\begin{array}{l}\text { Hungary } \\
\text { Mađarska }\end{array}$ & 0.736 & 0.382 & 0.003 & 30.0 \\
\hline 41 & $\begin{array}{l}\text { Poland } \\
\text { Poljska }\end{array}$ & 0.709 & 0.325 & - & 34.9 \\
\hline 49 & $\begin{array}{c}\text { Montenegro } \\
\text { Crna Gora }\end{array}$ & 0.693 & - & 0.006 & 36.9 \\
\hline 50 & $\begin{array}{l}\text { Romania } \\
\text { Rumunija }\end{array}$ & 0.675 & 0.478 & - & 32.1 \\
\hline 51 & $\begin{array}{c}\text { Croatia } \\
\text { Hrvatska }\end{array}$ & 0.650 & 0.345 & 0.007 & 47.1 \\
\hline 58 & $\begin{array}{l}\text { Bulgaria } \\
\text { Bugarska }\end{array}$ & 0.659 & 0.399 & - & 29.2 \\
\hline 60 & $\begin{array}{l}\text { Serbia } \\
\text { Srbija }\end{array}$ & 0.656 & - & 0.003 & 28.2 \\
\hline 64 & $\begin{array}{l}\text { Albania } \\
\text { Albanija }\end{array}$ & 0.719 & 0.545 & 0.004 & 33.0 \\
\hline 68 & $\begin{array}{c}\text { Bosnia and } \\
\text { Herzegovina } \\
\text { Bosna i } \\
\text { Hercegovina }\end{array}$ & 0.710 & - & 0.003 & 36.3 \\
\hline 71 & $\begin{array}{l}\text { Macedonia } \\
\text { Makedonija }\end{array}$ & 0,701 & - & 0.008 & 42.8 \\
\hline
\end{tabular}

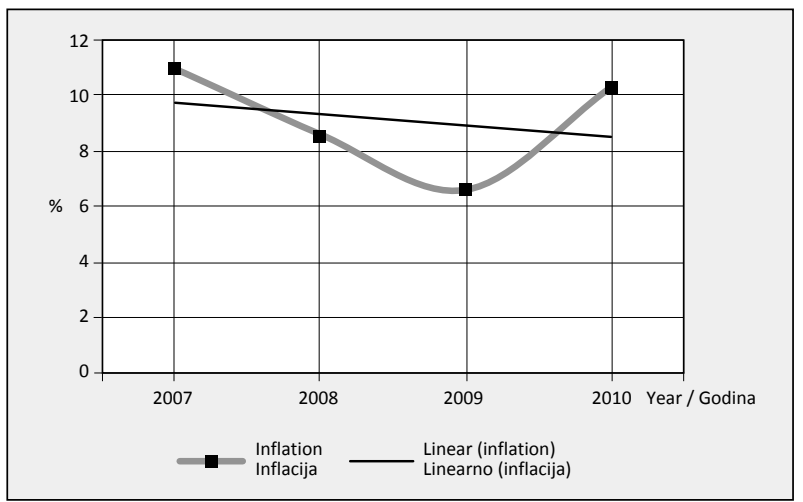

Graph 3. Total inflation (\%) in Serbia in the period 2006-2010 Grafikon 3. Ukupna inflacija (\%) u Srbiji u periodu 2006-2010. godine
Table 3. Average inflation in Serbia, the European Union and selected European countries in 2010

Tabela 3. Prosečna inflacija u Srbiji, Evropskoj Uniji i izabranim evropskim zemljama u 2010. godini

\begin{tabular}{|c|c|}
\hline $\begin{array}{l}\text { Country } \\
\text { Država }\end{array}$ & $\begin{array}{l}\text { Inflation } \\
\text { Inflacija }\end{array}$ \\
\hline $\begin{array}{l}\text { Albania } \\
\text { Albanija }\end{array}$ & $3.5 \%$ \\
\hline $\begin{array}{l}\text { Bulgaria } \\
\text { Bugarska }\end{array}$ & $3.0 \%$ \\
\hline $\begin{array}{l}\text { Croatia } \\
\text { Hrvatska }\end{array}$ & $1.1 \%$ \\
\hline $\begin{array}{l}\text { Czech Republic } \\
\text { Češka Republika }\end{array}$ & $1.2 \%$ \\
\hline $\begin{array}{l}\text { Hungary } \\
\text { Mađarska }\end{array}$ & $4.7 \%$ \\
\hline $\begin{array}{l}\text { Poland } \\
\text { Poljska }\end{array}$ & $2.7 \%$ \\
\hline $\begin{array}{l}\text { Romania } \\
\text { Rumunija }\end{array}$ & $6.1 \%$ \\
\hline $\begin{array}{l}\text { Serbia } \\
\text { Srbija }\end{array}$ & $6.5 \%$ \\
\hline $\begin{array}{l}\text { Slovakia } \\
\text { Slovačka }\end{array}$ & $0.7 \%$ \\
\hline $\begin{array}{l}\text { Slovenia } \\
\text { Slovenija }\end{array}$ & $2.1 \%$ \\
\hline $\begin{array}{l}\text { European Union } \\
\text { Evropska Unija }\end{array}$ & $2.1 \%$ \\
\hline $\begin{array}{l}\text { Bosnia and Herzegovina } \\
\text { Bosna i Hercegovina }\end{array}$ & $2.1 \%$ \\
\hline $\begin{array}{l}\text { Montenegro } \\
\text { Crna Gora }\end{array}$ & $0.5 \%$ \\
\hline $\begin{array}{l}\text { Macedonia } \\
\text { Makedonija }\end{array}$ & $2.6 \%$ \\
\hline $\begin{array}{l}\text { Turkey } \\
\text { Turska }\end{array}$ & $8.6 \%$ \\
\hline $\begin{array}{l}\text { Netherlands } \\
\text { Holandija }\end{array}$ & $0.9 \%$ \\
\hline $\begin{array}{l}\text { Greece } \\
\text { Grčka }\end{array}$ & $4.7 \%$ \\
\hline
\end{tabular}

in 2010 it was US $\$ 439$ (€ 330 ) only (Table 4 ). When comparing the average net wage in Serbia, with salaries in the health care and social work in the period 2006-2010, it is evident that wages in health care were significantly higher in 2008, while in 2010 they were almost equal to the average net wage (Graph 5). 


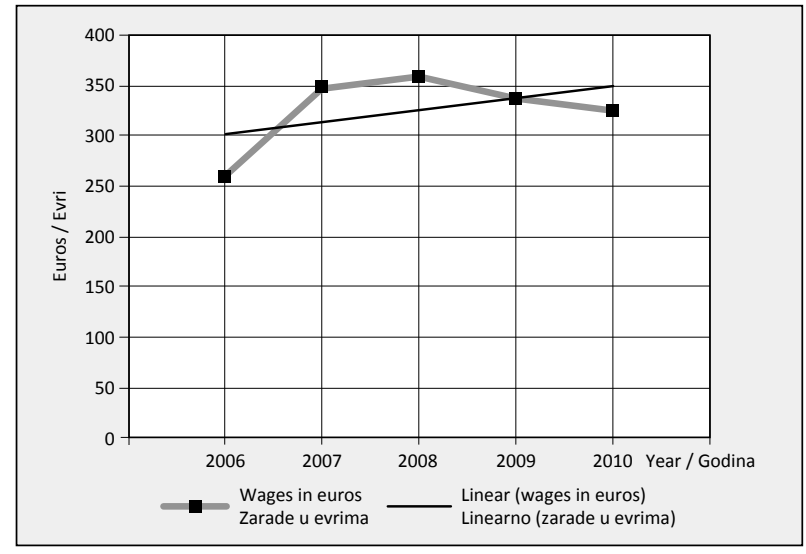

Graph 4. Growth rate of average real net wage (\%) in Serbia in the period 2006-2010

Grafikon 4. Stopa rasta prosečnih realnih neto zarada (\%) u Srbiji u periodu 2006-2010. godine

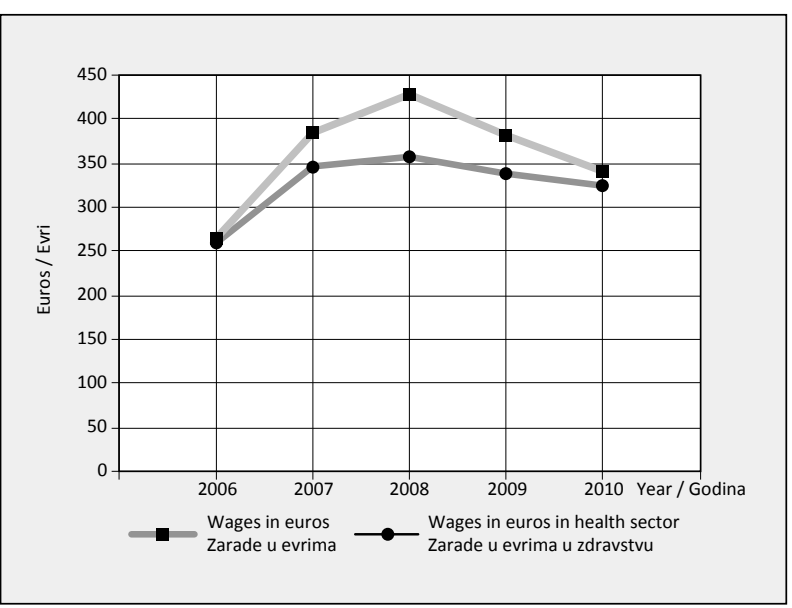

Graph 5. Growth rate of average net wage earnings in the health sector in Serbia in the period 2006-2010

Grafikon 5. Stopa rasta prosečnih neto zarada u Srbiji sa zaradama u zdravstvu u periodu 2006-2010. godine

The average monthly spending per household in Serbia in 2009 was 42,548 dinars and it was reduced to 42,448 dinars in 2010. The structure of personal consumption of households in 2009 was very similar to that in 2010 . The largest share in 2009 and 2010 was for food expenditures (41.2\% and $41.3 \%$, respectively), housing costs ( $16.1 \%$ and $16 \%$, respectively), while expenditure for health care ranged from $3.7 \%$ in 2009 to $4.1 \%$. in 2010 (Table 5).

Although household expenditure for health care in 2010 increased as compared to 2009 , the total health care spending per capita declined from US $\$ 673$ in 2008 to US $\$ 546$ in 2010 (Table 6). About $62 \%$ of total expenditure of health care was financed from public sources in 2010 in Serbia, mostly by RHIF. The part of the funds for health services was provided through the Ministry of Health, regional and local governments, the Ministry of Defence, the Ministry of Justice and the Military Health Insurance (Graphs 6 and 7). From previous graphs one can see that the Republic Health Insurance Fund payments mostly determined providing public health services.

According to the Chamber of Medical Institutions, from 2006 to 2008 steady increase of permanent employees in the public health sector was recorded. In 2009 the
Table 4. Average real wages in all sectors and health sector in Serbia Tabela 4. Prosečne realne zarade u svim sektorima i zdravstvu u Srbiji

\begin{tabular}{|l|c|c|c|c|c|}
\hline $\begin{array}{l}\text { Wages (in Euro) } \\
\text { Plate (evri) }\end{array}$ & $\mathbf{2 0 0 6}$ & $\mathbf{2 0 0 7}$ & $\mathbf{2 0 0 8}$ & $\mathbf{2 0 0 9}$ & $\mathbf{2 0 1 0}$ \\
\hline $\begin{array}{l}\text { All sectors } \\
\text { Svi sektori }\end{array}$ & 260 & 348 & 359 & 338 & 330 \\
\hline $\begin{array}{l}\text { Health sector } \\
\text { Sektor zdravstva }\end{array}$ & 265 & 385 & 428 & 383 & 342 \\
\hline
\end{tabular}

Table 5. Individual consumption in Serbia in 2009 and 2010

Tabela 5. Lična potrošnja domaćinstava u Srbiji u 2009. i 2010. godini

\begin{tabular}{|l|c|c|}
\hline $\begin{array}{l}\text { Type of consumption } \\
\text { Vrsta potrošnje }\end{array}$ & $\mathbf{2 0 0 9}$ & $\mathbf{2 0 1 0}$ \\
\hline $\begin{array}{l}\text { Food } \\
\text { Hrana }\end{array}$ & $41.2 \%$ & $41.3 \%$ \\
\hline $\begin{array}{l}\text { Housing } \\
\text { Stanovanje }\end{array}$ & $16.1 \%$ & $16.0 \%$ \\
\hline $\begin{array}{l}\text { Other } \\
\text { Ostalo }\end{array}$ & $11.1 \%$ & $11.3 \%$ \\
\hline $\begin{array}{l}\text { Transport } \\
\text { Prevoz }\end{array}$ & $9.0 \%$ & $9.0 \%$ \\
\hline $\begin{array}{l}\text { Clothes } \\
\text { Odeća }\end{array}$ & $5.1 \%$ & $4.8 \%$ \\
\hline $\begin{array}{l}\text { Alcohol and tobacco } \\
\text { Alkohol i duvan }\end{array}$ & $4.5 \%$ & $4.4 \%$ \\
\hline $\begin{array}{l}\text { Furniture } \\
\text { Nameštaj }\end{array}$ & $4.4 \%$ & $4.4 \%$ \\
\hline $\begin{array}{l}\text { Recreation } \\
\text { Rekreacija }\end{array}$ & $4.7 \%$ & $4.7 \%$ \\
\hline $\begin{array}{l}\text { Health } \\
\text { Zdravlje }\end{array}$ & $3.1 \%$ \\
\hline
\end{tabular}

Table 6. Total expenditure on health care in the period 2006-2010 Tabela 6. Ukupni rashodi za zdravstvenu zaštitu u periodu 2006-2010. godine

\begin{tabular}{|l|c|c|c|c|c|}
\hline $\begin{array}{l}\text { Year } \\
\text { Godina }\end{array}$ & $\mathbf{2 0 0 6}$ & $\mathbf{2 0 0 7}$ & $\mathbf{2 0 0 8}$ & $\mathbf{2 0 0 9}$ & $\mathbf{2 0 1 0}$ \\
\hline $\begin{array}{l}\text { Total expenditure (dollars) } \\
\text { Ukupni troškovi (dolari) }\end{array}$ & 371 & 547 & 673 & 577 & 546 \\
\hline
\end{tabular}

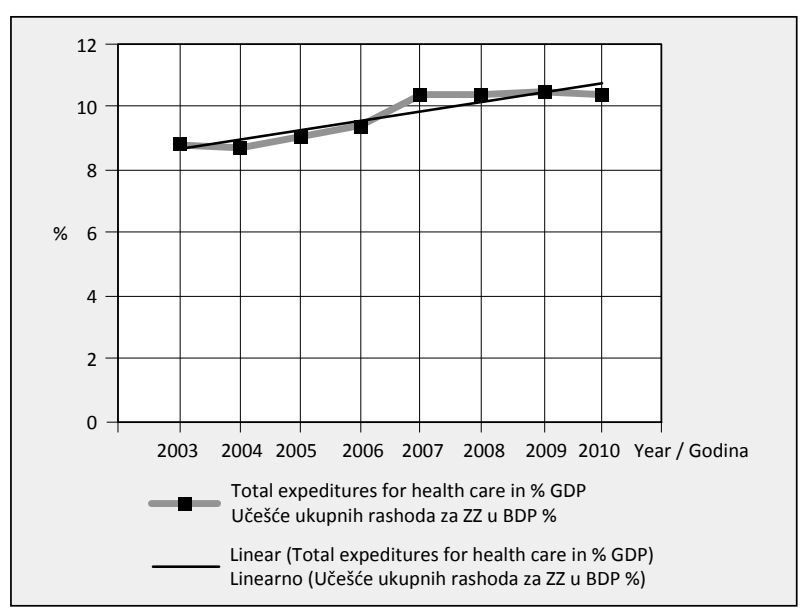

Graph 6. Total expenditure on health care (\% GDP) Grafikon 6. Ukupni rashodi za zdravstvenu zaštitu (\% BDP)

number of permanent employees decreased while again increased in 2010 (Table 7). The number of temporary employees varied greatly in different types of health care facilities and increased the total number of employees in the public health sector. The total number of employees in the health sector also recorded an increase in the period 2006-2008. However, in 2009 and 2010, the total 
number of employees was reduced (Table 7). The largest number of temporary employees was in Emergency Care (Table 8).

The structure of the overall financing of the public health system showed that the majority of funding was spent for salaries of the employees in the public health institutions. Funds for employees in public health care

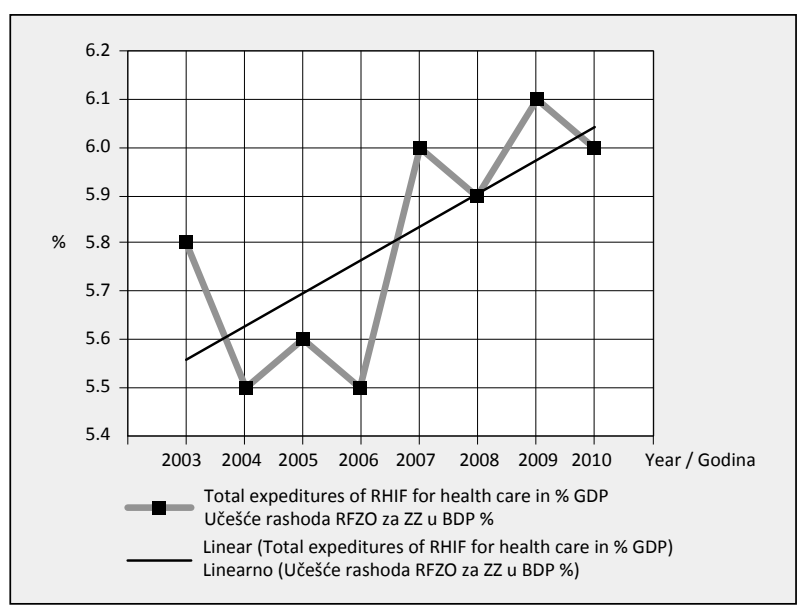

Graph 7. Total expeditures of the Republic Health Insurance Fund (\% GDP)

Grafikon 7. Rashodi Republičkog fonda za zdravstveno osiguranje (\% BDP)

Table 7. Total number of employees in the public health sector in the period 2006-2010

Tabela 7. Ukupan broj zaposlenih u javnozdravstvenom sektoru u periodu 2006-2010. godine

\begin{tabular}{|l|c|c|c|c|c|}
\hline $\begin{array}{l}\text { Year } \\
\text { Godina }\end{array}$ & $\mathbf{2 0 0 6}$ & $\mathbf{2 0 0 7}$ & $\mathbf{2 0 0 8}$ & $\mathbf{2 0 0 9}$ & $\mathbf{2 0 1 0}$ \\
\hline $\begin{array}{l}\text { Permanent employees } \\
\text { Stalno zaposleni }\end{array}$ & 108975 & 111068 & 114317 & 114175 & 114432 \\
\hline $\begin{array}{l}\text { Permanent and } \\
\text { temporary employees } \\
\text { Stalno i privremeno } \\
\text { zaposleni }\end{array}$ & 125081 & 126977 & 129357 & 128694 & 122695 \\
\hline
\end{tabular}

Table 8. Temporary employees in the public health care institutions in Serbia in 2010

Tabela 8. Zaposleni na određeno vreme u različitim javnozdravstvenim ustanovama Srbije u 2010. godini

\begin{tabular}{|l|c|}
\hline $\begin{array}{l}\text { Health care institution } \\
\text { Zdravstvena ustanova }\end{array}$ & $\begin{array}{l}\text { Temporary employees } \\
\text { Privremeno zaposleni }\end{array}$ \\
\hline $\begin{array}{l}\text { Hospital } \\
\text { Bolnica }\end{array}$ & $7.6 \%$ \\
\hline $\begin{array}{l}\text { Psychiatry } \\
\text { Psihijatrija }\end{array}$ & $6.1 \%$ \\
\hline $\begin{array}{l}\text { Special hospital } \\
\text { Specijalna bolnica }\end{array}$ & $7.6 \%$ \\
\hline $\begin{array}{l}\text { Rehabilitation } \\
\text { Rehabilitacija }\end{array}$ & $7.6 \%$ \\
\hline $\begin{array}{l}\text { Health centre with beds } \\
\text { Dom zdravlja sa krevetom }\end{array}$ & $6.4 \%$ \\
\hline $\begin{array}{l}\text { Health centre without beds } \\
\text { Dom zdravlja bez kreveta }\end{array}$ & $6.3 \%$ \\
\hline $\begin{array}{l}\text { Emergency care } \\
\text { Hitna medicinska pomoć }\end{array}$ & $8.8 \%$ \\
\hline $\begin{array}{l}\text { Pharmacy } \\
\text { Apoteka }\end{array}$ & $7.5 \%$ \\
\hline $\begin{array}{l}\text { Public health } \\
\text { Javno zdravlje }\end{array}$ & $6.3 \%$ \\
\hline
\end{tabular}

were distributed differently. Table 9 showed that the greatest amount of finances was paid to the hospital staff.

In 2009 and 2010 the economic activity slowed down in Serbia, leading to increased unemployment and earning slowdown. The total number of employees in 2010 was reduced for $4.66 \%$ as compared to 2009 . The unemployment rate in 2009 increased to $16.1 \%$ as compared to $13.6 \%$ in 2008. In 2010, with slight recovery of the economic activity the reduction of unemployment was expected, however it did not happen and the unemployment rate increased to $19.2 \%$, while the employment rate declined for $4.9 \%$ (Graph 8). The unemployment rate in Serbia is still the highest as compared to the Euro-zone countries and neighboring countries, except for Bosnia and Herzegovina (Table 10). The unemployment rate in the public health care sector was different for nurses and doctors in the observed period. The number of unemployed nurses was significantly higher in 2006 as compared to 2010, but the number of unemployed doctors

Table 9. Structure of funds for employees in the public health sector in 2010

Tabela 9. Raspored finansijskih sredstava za zaposlene u javnom zdravstvu u 2010. godini

\begin{tabular}{|l|c|}
\hline $\begin{array}{l}\text { Health care institution } \\
\text { Zdravstvena ustanova }\end{array}$ & $\begin{array}{c}\text { Funds } \\
\text { Finansije }\end{array}$ \\
\hline $\begin{array}{l}\text { Hospital } \\
\text { Bolnica }\end{array}$ & $42.64 \%$ \\
\hline $\begin{array}{l}\text { Psychiatry } \\
\text { Psihijatrija }\end{array}$ & $1.42 \%$ \\
\hline $\begin{array}{l}\text { Special hospital } \\
\text { Specijalna bolnica }\end{array}$ & $9.42 \%$ \\
\hline $\begin{array}{l}\text { Rehabilitation } \\
\text { Rehabilitacija }\end{array}$ & $3.01 \%$ \\
\hline $\begin{array}{l}\text { Health centre with beds } \\
\text { Dom zdravlja sa krevetom }\end{array}$ & $3.05 \%$ \\
\hline $\begin{array}{l}\text { Health centre without beds } \\
\text { Dom zdravlja bez kreveta }\end{array}$ & $30.74 \%$ \\
\hline $\begin{array}{l}\text { Emergency care } \\
\text { Hitna medicinska pomoć }\end{array}$ & $1.21 \%$ \\
\hline $\begin{array}{l}\text { Pharmacy } \\
\text { Apoteka }\end{array}$ & $3.78 \%$ \\
\hline $\begin{array}{l}\text { Public health } \\
\text { Javno zdravlje }\end{array}$ & $2.37 \%$ \\
\hline $\begin{array}{l}\text { Other } \\
\text { Ostalo }\end{array}$ & $2.34 \%$ \\
\hline
\end{tabular}

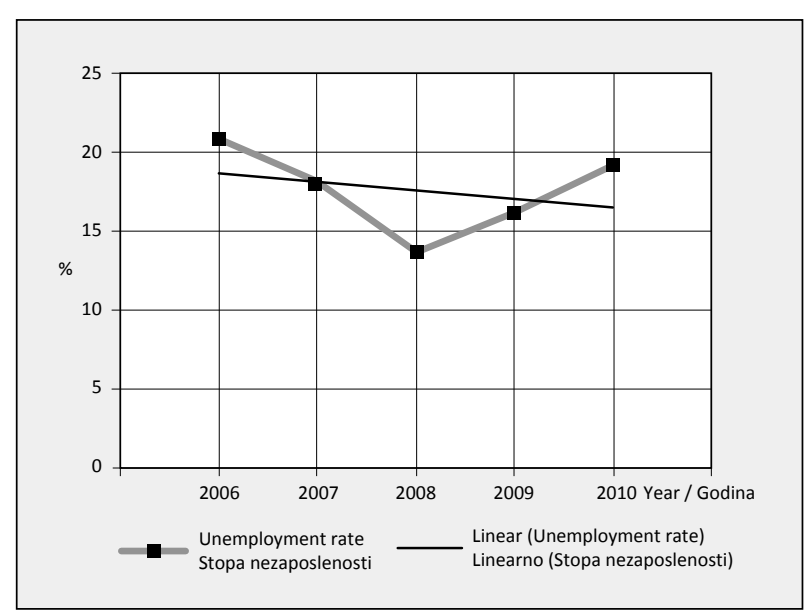

Graph 8. Unemployment rate (\%) Grafikon 8. Stopa nezaposlenosti (\%) 
in 2010 was doubled as compared to 2006. The unemployment rate in the public health care sector is shown in Tables 11 and 12.

\section{DISCUSSION}

GDP in Serbia, the most important macroeconomic aggregate, is the measure of total economic activity of all resident institutional units. It includes the production of material goods as well as all kinds of services. In the period 2006-2008, there has been a significant increase

Table 10. Unemployment rate in Serbia, the European Union and other selected European countries in 2010

Tabela 10. Stopa nezaposlenosti u Srbiji, Evropskoj Uniji i izabranim evropskim zemljama u 2010. godini

\begin{tabular}{|l|c|}
\hline $\begin{array}{l}\text { Country } \\
\text { Država }\end{array}$ & $\begin{array}{c}\text { Unemployment rate } \\
\text { Stopa nezaposlenosti }\end{array}$ \\
\hline $\begin{array}{l}\text { Bosnia and Herzegovina } \\
\text { Bosna i Hercegovina }\end{array}$ & $27.2 \%$ \\
\hline $\begin{array}{l}\text { Norway } \\
\text { Norveška }\end{array}$ & $3.5 \%$ \\
\hline $\begin{array}{l}\text { Bulgaria } \\
\text { Bugarska }\end{array}$ & $10.2 \%$ \\
\hline $\begin{array}{l}\text { Croatia } \\
\text { Hrvatska }\end{array}$ & $11.8 \%$ \\
\hline $\begin{array}{l}\text { Czech Republic } \\
\text { Čška Republika }\end{array}$ & $7.3 \%$ \\
\hline $\begin{array}{l}\text { Estonia } \\
\text { Estonija }\end{array}$ & $16.9 \%$ \\
\hline $\begin{array}{l}\text { Hungary } \\
\text { Mađarska }\end{array}$ & $11.2 \%$ \\
\hline $\begin{array}{l}\text { Greece } \\
\text { Grčka }\end{array}$ & $12.6 \%$ \\
\hline $\begin{array}{l}\text { Poland } \\
\text { Poljska }\end{array}$ & $7.6 \%$ \\
\hline $\begin{array}{l}\text { Romania } \\
\text { Rumunija }\end{array}$ & $9.7 \%$ \\
\hline $\begin{array}{l}\text { Serbia } \\
\text { Srbija }\end{array}$ & $7.3 \%$ \\
\hline $\begin{array}{l}\text { Slovakia } \\
\text { Slovačka }\end{array}$ & $19.2 \%$ \\
\hline $\begin{array}{l}\text { Slovenia } \\
\text { Slovenija }\end{array}$ & \\
\hline $\begin{array}{l}\text { European Union } \\
\text { Evropska Unija }\end{array}$ & \\
\hline
\end{tabular}

Table 11. Unemployment rate of nurses in 2006 and 2010

Tabela 11. Stopa nezaposlenosti medicinskih sestara 2006. i 2010. godine

\begin{tabular}{|c|c|c|c|c|c|c|}
\hline \multirow{2}{*}{$\begin{array}{c}\text { Year } \\
\text { Godina }\end{array}$} & \multicolumn{2}{|c|}{$\begin{array}{c}\text { Unemployed } \\
\text { Nezaposleni }\end{array}$} & \multicolumn{2}{c|}{$\begin{array}{c}\text { Younger than 25 years } \\
\text { Mlađi od 25 godina }\end{array}$} & \multicolumn{2}{c|}{$\begin{array}{c}\text { Waiting more than 1 year for work } \\
\text { Cekaju na posao duže od godinu dana }\end{array}$} \\
\cline { 2 - 6 } & $\begin{array}{c}\text { Total } \\
\text { Ukupno }\end{array}$ & $\begin{array}{c}\text { Women } \\
\text { Žene }\end{array}$ & $\begin{array}{c}\text { Total } \\
\text { Ukupno }\end{array}$ & $\begin{array}{c}\text { Women } \\
\text { Žene }\end{array}$ & $\begin{array}{c}\text { Total } \\
\text { Ukupno }\end{array}$ & $\begin{array}{c}\text { Women } \\
\text { Žene }\end{array}$ \\
\hline 2006 & $7109(100 \%)$ & $6506(91.52 \%)$ & $3419(48.09 \%)$ & $3092(43.49 \%)$ & $4227(59.46 \%)$ & $3885(54.65 \%)$ \\
\hline 2010 & $4623(100 \%)$ & $4254(92.02 \%)$ & $1857(40.17 \%)$ & $1654(35.78 \%)$ & $2559(55.35 \%)$ & $2389(56.16 \%)$ \\
\hline
\end{tabular}

Table 12. Unemployment rate of medical doctors in 2006 and 2010

Tabela 12. Stopa nezaposlenosti lekara 2006. i 2010. godine

\begin{tabular}{|c|c|c|c|c|c|c|}
\hline \multirow{2}{*}{$\begin{array}{c}\text { Year } \\
\text { Godina }\end{array}$} & \multicolumn{2}{|c|}{$\begin{array}{c}\text { Unemployed } \\
\text { Nezaposleni }\end{array}$} & \multicolumn{2}{c|}{$\begin{array}{c}\text { Younger than 25 years } \\
\text { Mlađi od 25 godina }\end{array}$} & \multicolumn{2}{c|}{$\begin{array}{c}\text { Waiting more than 1 year for work } \\
\text { Cekaju na posao duže od godinu dana }\end{array}$} \\
\cline { 2 - 7 } & $\begin{array}{c}\text { Total } \\
\text { Ukupno }\end{array}$ & $\begin{array}{c}\text { Women } \\
\text { Žene }\end{array}$ & $\begin{array}{c}\text { Total } \\
\text { Ukupno }\end{array}$ & $\begin{array}{c}\text { Women } \\
\text { Žene }\end{array}$ & $\begin{array}{c}\text { Total } \\
\text { Ukupno }\end{array}$ & $\begin{array}{c}\text { Women } \\
\text { Žene }\end{array}$ \\
\hline 2006 & $795(100 \%)$ & $557(70 \%)$ & $521(65.53 \%)$ & $371(46.67 \%)$ & $356(44.78 \%)$ & $248(31.19 \%)$ \\
\hline 2010 & $1706(100 \%)$ & $1295(74.42 \%)$ & $953(59.19 \%)$ & $711(43.42 \%)$ & $718(42.09 \%)$ & $585(45.17 \%)$ \\
\hline
\end{tabular}

of GDP. The growth of GDP in observed period was achieved thanks to the positive structural reforms and realized investmenst, however, the greatest impact was from increasing household demands, sale growth, salaries, pensions, loans and imports [1]. According to the 2009 for about $7 \%$ caused by decrease of foreign capital, slowdown of lending activity and significant slowdown in earnings growth. However, there was a slight increase in GDP up to $1 \%$ in 2010 , which was based on the growth of exported demands and investment spending. In 2009, the global economic crisis has stopped relatively rapid economic development in Serbia. However, the crisis caused deacrease in GDP per capita in 2010 to US $\$ 5,006$ ( $€$ 3,781 ) from US $\$ 6,498$ (€ 4,445) in 2008 .

The global economic crisis affected all countries. After a decade of positive growth rates, all countries in Europe, except Poland and Germany, recorded negative growth rate of real GDP in 2009. Serbia, however, recorded a smaller decline in GDP than the average European Union $(-4.2 \%)$, most European countries and countries in the region. Large fall in GDP (at least twice) was recorded in the number of European countries: Estonia (-13.9\%), Ireland $(-7.6 \%)$, Latvia $(-18 \%)$, Lithuania $(-14.7 \%)$, Hungary $(-6.7 \%)$, Romania $(-7.1 \%)$, Slovenia $(-8.1 \%)$, Finland (-8\%) and Iceland (-6.8\%) [2]. Of the neighboring countries, Macedonia showed significantly lower decline of GDP for only $-0.7 \%$.

Serbia's foreign debt in 2010 was $41.4 \%$ of GDP (as below $80 \%$, Serbia does not belong to the category of highly indebted economy, according to World Bank criteria). Foreign direct investments were falling down since 2006; in 2009 they were just $4.4 \%$ of GDP, whereas in 2010 they were even lower, $3 \%$ of GDP [3, 4]. Since 2009 , the official measure of the inflation in Serbia was named overall inflation and measured by the annual percentage change in the Consumer Price Index. It is socalled harmonized price index, a separate index of retail prices, calculated by the methodology harmonized with EU recommendations. It reflects the change in price of fixed basket of goods and services that consumers buy to meet their needs (the list of products and services also includes financial services, education, insurance, hospitality and health services). The statistical office calculated Republic Development Fund, there was a fall in GDP in 
this index for the last two years and there has been continuous decline in the overall inflation till 2010, when it grew for $3.7 \%$. At the same time, the National Fund of Statistics changed the methodology for the calculation of retail price indexes; therefore, these parameters were not comparable for this period. However, the average level of the inflation was much higher in Serbia each year in the observed period as compared to the average of the Europian Union. There were also differences in the level of the inflation between countries. As compared to the neighboring countries, except Romania, Serbia had significantly higher rate of the inflation $[5,6,7]$.

World economic and financial crisis at the end of 2008 resulted in destabilization of foreign exchange market. In order to stabilize the market, the Government imposed many anti-inflation measures, such as the measure of "freezing" of pensions and public wages. Also, an agreement on the target inflation between the Government of Serbia and the Serbian National Bank was signed.

The deterioration of macroeconomic indicators led to the falling of living standards. During the observed period the fluctuation rates of poverty risk were determined. In 2008, 580,000 people were living below the absolute poverty line of 7,937 dinars ( $€ 97.5$ or US $\$ 142.5$ ) per consumer unit per month, which gave the poverty rate of $7.9 \%$. In $2009,652,218$ people were living below the absolute poverty line while in 2010 that number increased to 670,812 people. The economic crisis in 2010 caused an increase in the number of poor people, so that $9.2 \%$ of the population lived below the absolute poverty line of 8,544 dinars (€103, US \$150) per month. The risk of poverty is an indicator of social exclusion, which is not the choice but the consequence of unequal distribution of national wealth, poor social solidarity, inequalities in access to opportunities and inconsistencies in the implementation of declared global and European commitments and standards. The risk of poverty in the European Union in 2008 was $16.5 \%$, in Slovenia $12.3 \%$, while in Serbia it was $20.6 \%$ by the Republic Development Fund. Serbia has a high risk of poverty with the most vulnerable categories of seniors and children under 15 years.

During the reporting period, the composite human development index (HDI) as an indicator of life quality and interdependence between economic and social development expressed by the average achievements of the country in health, education and living standards (measured by GDP per capita at purchasing power) increased. A significant increase of HDI in 2010 (0.735) was the result of increasing life expectancy and rising purchasing power index. Comparing to the countries in the region in 2007 it was obvious that Albania (0.719), Macedonia (0.701) and Bosnia and Herzegovina (0.710) had low HDI, while Slovenia had high value of HDI (0.929) [8].

Expenditures for health care showed steady increase in the period 2006- 2010, both in total amount, and for each studied component: the expenditure of the Health Insurance Institute, the public expenditure and the private expenditure for health care. Spending on health care as the percentage of GDP showed that Serbia (10.4\%) was above the EU average (9\% in 2008), approximately at the level of Austria, Germany, Portugal, Switzerland, Bosnia and Herzegovina [9]. Expenditures on health care in Serbia were significantly higher than in Bulgaria, the Czech Republic, Estonia, Spain, Cyprus, Lithuania, Luxembourg, Hungary, Poland, Romania, Slovenia, and Sweden.

The Government conducted restrictive fiscal policy, including freezing public sector wages and pensions, and reduction of public spending in 2009. During the whole period, with the exception of 2008 , the average real wage growth was much higher than the growth of overall economic activity and productivity. As compared to the neighboring countries, the net earnings of $€ 338$ in Serbia in 2009 was higher than in Bulgaria and Albania, but lower than in Bosnia and Herzegovina ( $€ 410)$, Hungary (€ 458), Croatia (€ 737) and Slovenia (€ 930). Romania and Macedonia were approximately on the same level [9].

Salaries of employees in the public helth care institutions are almost entirely funded by the Republican Health Insurance Fund (RHIF). The remuneration system in heath care is still input-based, and employees' earnings have by far the largest share in overall costs in the health care service. The growth of expenditures for employees in the health sector for the period 2006 to 2010 showed slower increase in salaries than increase of the total expediture, which was in agreement with planned decrease of expenditures for employees in RHIF. RHIF revenues in the period 2006 to 2010 increased in total for $65 \%$, whereas gross salaries increased in total for $60 \%$. Comparing the data on revenues and salaries for the health care employees in 2008 with the data for 2010, it can be concluded that the share of total expenditures for employees decreased from $61.20 \%$ in 2008 to $56.21 \%$ in 2010 [10].

Acording to the data obtained from the Chamber of health institutions for 2010, compensations for employees in the public health sector recorded nominal increase of $3.16 \%$ in 2009 . The cost of living in 2009 on average increased for $8.6 \%$ as compared to the average of the previous year. In other words, compared to the previous year, these expenses were actually lower for $5.1 \%$.

Unemployment in Serbia is a major economic and social problem since the pre-transition period and became worse during the process of ownership transformation, enterprise restructuring and the crisis in 2009 and 2010. The labor market in Serbia differs according to the affiliation to the public or private sector, where employees in the public sector have high job security while the private sector continues to decrease the number of employees due to the crisis. The unemployment rate in Serbia in 2010 reached 19.2\%. In 2009 it was 16.6\%, while in the same year the average unemployment rate of 27 European Union countries was $9.3 \%$ and in the euro zone, it was $9.8 \%[5,6,7]$. The lowest rate was in Norway (3.2\%). The labor market situation was further complicated by the fact that $65.5 \%$ of the total number of unemployed in 2009 belonged to the category of longterm unemployed (waiting for the employment more than one year). This indicates a high degree of social exclusion. Long-term unemployment rate in Serbia as 
compared to the European Union, the euro-zone countries and all countries in the region (in EU 33.7\%, in Slovenia $27.5 \%$ ) was significantly higher (65.5\%) in 2009. Very long term unemployment rate (8.1\%) was extremely high as compared to the average of the European Union and neighboring countries (EU 1.5\%, Slovenia 0.9\%). The unemployment rate of women in Serbia (18.4\%) was significantly higher than in the European Union (9.1\%) and Slovenia $(6.4 \%)$ in 2009 . The unemployment rate of young people (15 - 24 years) in Serbia (42.5\%) was significantly higer that the average rate of youth unemployment in the European Union (21.4\%) and Slovenia $(15.7 \%)$. The employment rate in Serbia of $60.5 \%$ was the lowest as compared to the European Union and neighboring countries. The average employment rate in the European Union and Slovenia was $71.3 \%$ in 2009. The employment rate of working-age population in Serbia $(50 \%)$ was significantly lower as compared to the average employment rate in the European Union (64.8\%) in 2009. In the public health sector, the number of unemployed nurses decreased while the number of unemployed doctors rapidly increased in the in the observed period of five years. The number of unemployed nurses was significantly higher in $2006(7,109)$ as compared to $2010(4,623)$ [11]. Unemployment structure was similar, except for the category of young unemployed women and unemployed youth that had lower rate in $2010(40.17 \%$ and $35.78 \%)$ as compared to 2006 when youth unemployment $<25$ years was $48.09 \%$ and women $<25$ was $43.49 \%$. The number of unemployed doctors in 2010 was doubled as compared to the number of unemployed in 2006, but with smaller percentage of youth and those who have waited more than one year for employment. It is obvious that economic trends caused the increase of unemployment rate in the public health sector in a way that doctors were more affected by the the crisis and reduced expenditures for employees in public sector health care.

Problems with funding of the public health sector were also noted in other transition countries such as Kyrgyzstan, Tajikistan, Kazakhstan and Latvia [12].

Given that the greatest fundigs is available to the health care employees in the public sector, similar finan- cial problems are present in other countries [13] except in highly developed countries, that are facing the problem of lack of doctors and other highly educated medical staff. The number of studies is referring to the problem of shortage of medical doctors in some countries [14].

\section{CONCLUSION}

Results from the current study suggested that the world economic crisis had negative impact not only on GDP growth rate, the inflation and the unemployment rate, but on the public health sector workforce in the Republic of Serbia, their salaries and unemployment rate.

\section{REFERENCES}

1. Republički fond za razvoj. Izveštaj o razvoju Srbije; 2010.

2. Eurostat. Available from: http://epp.eurostat.ec.europa.eu.

3. Republički zavod za statistiku Srbije. Available from: http://webrzs. stat.gov.rs.

4. Ministarstvo finansija. Available from: http://www.mfin.gov.rs.

5. Eurostat. Available from: http://epp.eurostat.ec.europa.eu.

6. UNECE. Available from: http://w3.unece.org/pxweb/Dialog.

7. Republički zavod za statistiku Srbije. Available from: http://webrzs. stat.gov.rs/axd/index.php.

8. UNDP Database. Available from: http://www.un.org/en/databases.

9. WHO. European Health for All Database (HFA-DB). Copenhagen: WHO Regional Office for Europe; 2010. Available from: http:// data.euro.who.int/hfadb/www.swpho.nhs.uk/resource/item.aspx?.

10. Institut za javno zdravlje Srbije. Available from: http://www.batut. org.rs/index.php?category_id=50.

11. Nacionalna služba za zapošljavanje. Available from: http://www. nsz.gov.rs.

12. ECA Knowledge Brief: Mitigating the Impact of the Economic Crisis on Public Sector Health Spending, Pia Schneider. Available from: http://web.worldbank.org/WBSITE/EXTERNAL/COUNTRIES.

13. Thailand's Health Workforce: A Review of Challenges and Experiences. Available from: siteresources.worldbank.org/HEALTHNUTRITIONANDPOPULATION/ Resources/281627-1095698140167/THLHealthWorkforce.pdf.

14. Human Resources for Health: Overcoming the Crisis. Available from: www.who.int/hrh/documents/JLi_hrh_report.pdf.

Received: 01/03/2012 • Accepted: 20/04/2012 


\title{
Radna snaga u javnom sektoru zdravstvenog sistema Republike Srbije i svetska ekonomska kriza
}

\author{
Milena Gajić-Stevanović1, Darinka Perišić-Rainicke², Snežana Dimitrijević', Nevenka Teodorović3, \\ Slavoljub Živković3 \\ "Institut za javno zdravlje Srbije „Dr Milan Jovanović Batut”, Beograd, Srbija; \\ 2Univerzitet Šefild, Beograd, Srbija; \\ ${ }^{3}$ Stomatološki fakultet, Univerzitet u Beogradu, Beograd, Srbija
}

\begin{abstract}
KRATAK SADRŽAJ
Uvod Zdravstvena zaštita, kao jedna od najvažnijih i osetljivijih oblasti ljudskog delovanja, ima značajnu društvenu funkciju, pa promene u ovoj oblasti imaju široke implikacije na društvo u celini. Najnovija ekonomska kriza dovela je do sporog rasta bruto domaćeg proizvoda (BDP), visoke stope nezaposlenosti, nižeg životnog standarda i povećanja broja siromašnih širom sveta. Ovo uključuje i smanjenje kapaciteta zdravstvenog sistema, odnosno smanjenje obima i kvaliteta pruženih zdravstvenih usluga. Cilj rada bio je da se procene mogući uticaji svetske ekonomske krize na radnu snagu u javnom sektoru zdravstvenog sistema Republike Srbije.

Materijal i metode rada Retrospektivno su analizirani podaci o ljudskim resursima Instituta za javno zdravlje Srbije (IZJZS), baze podataka i publikacije Republičkog zavoda za statistiku, Republičkog fonda za razvoj, izveštaji Republičkog zavoda za tržište rada i podaci o zdravstvenim rashodima dobijeni iz izveštaja Komore zdravstvenih ustanova. Komparativna analitička metoda je korišćena za procenu socioekonomskih indikatora i kretanja ljudskih resursa tokom petogodišnjeg perioda (2006-2010. godine). Rezultati Studija je pokazala da je svetska ekonomska kriza prekinula konstantan privredni rast u Srbiji. Između 2006. i 2008. godine realna stopa rasta BDP je fluktuirala između 3,6\% i 5,4\%, dok je u 2009. imala negativnu stopu rasta od -3,1\% i blagi porast od $1 \%$ u 2010. U 2006. godini BDP po stanovniku bio je 3.943 američka dolara, a 2008. skoro dvostruko veći, dostigavši 6.498 dolara, dok je u 2009. pao na 5.499 dolara i nastavio da se smanjuje do 5.006 dolara u 2010. U 2007. godini ukupna inflacija bila je 6,5\%, a posle fluktuiranja između 11,7\% u 2008. i 8,4\% u 2009, da bi se u 2010. ponovo smanjila na 6,5\%. Prema podacima IZJZS, od 2006. do 2008. godine zabeleženo je stalno povećanje broja zaposlenih u javnom sektoru zdravstva sa 108.975 na 114.317. U 2009. broj stalno zaposlenih neznatno se smanjio na 114.175, odnosno na 114.432 u 2010. godini. Primećeno je konstantno povećanje ukupnog broja zaposlenih u javnom sektoru zdravstva, sa 125.081 u 2006. na 129.357 u 2008. U 2009. godini ukupan broj zaposlenih je smanjen na 128.694, a u 2010. na 122.695. Istovremeno, ukupni rashodi za ljudske resurse u javnom sektoru zdravstvenog sistema u odnosu na ukupne troškove za zdravstvenu zaštitu smanjeni su sa 37,7\% u 2006. na 34,7\% u 2010. Zarade zaposlenih u javnom sektoru zdravstvenog sistema Republike Srbije su se posle neprekidnog povećanja od 59,9\% ukupnih troškova lečenja u 2006, preko $61,2 \%$ u 2007. i 2008. godini, smanjile na 56,2 \% u 2010. Stopa nezaposlenosti za lekare se skoro udvostručila u 2010. u poređenju sa 2006. godinom.

Zaključak Preliminarni rezultati studije su pokazali da je svetska ekonomska kriza loše uticala ne samo na stopu rasta BDP, inflaciju i nezaposlenost, već i na javni zdravstveni sektor, radnu snagu, plate i stopu nezaposlenosti u Republici Srbiji.
\end{abstract}

Ključne reči: radna snaga; javni zdravstveni sektor; svetska ekonomska kriza

\section{UVOD}

Zdravstvena zaštita, kao jedna od najvažnijih i osetljivijih oblasti ljudskog delovanja, ima značajnu društvenu funkciju, pa promene u ovoj oblasti imaju široke implikacije na društvo u celini. Najnovija ekonomska kriza dovela je do sporog rasta bruto domaćeg proizvoda (BDP), visoke stope nezaposlenosti, nižeg životnog standarda i povećanja broja siromašnih širom sveta. Naučene lekcije iz prošlosti u vezi s ekonomskim katastrofama pokazuju da kriza može da ugrozi društveni napredak na više načina, uključujući smanjenje kapaciteta zdravstvenog sistema, izraženog kroz smanjenje obima i kvaliteta pruženih zdravstvenih usluga. Radno okruženje, kao i ljudski, finansijski i tehnički kapaciteti javnog zdravstva, menjaju se istovremeno s ekonomskom tranzicijom.

Socioekonomski pokazatelji razvojne pozicije Srbije pretrpeli su u 2009. i 2010. godini značajne uticaje globalne ekonomske krize, koja se smatra najvećom od „velike depresije” tridesetih godina dvadesetog veka. Međutim, razvojni položaj Srbije u Evropi je stabilan. Srbija se nalazi na 35. mestu, kako u pogledu ekonomskog razvoja (BDP po kupovnoj moći po stanovniku), tako i s aspekta ljudskog razvoja (vrednosti indeksa ljudskog razvoja). Pod uticajem svetske ekonomske krize globalni ekonomski temelji se menjaju, što neminovno dovodi do nedovoljnog finansiranja zdravstvene zaštite i u Srbiji. Zdravstveni sistem je finansiran obaveznim doprinosima za zdravstveno osiguranje, izdvajanjem 12,3\% od zarada. U svetlu društveno-ekonomskih promena na globalnom nivou, menja se i društveno-ekonomski kontekst u kojem zdravstveni radnici u Srbiji rade i organizacije funkcionišu.

Cilj ovog rada bio je da se procene mogući uticaji svetske ekonomske krize na radnu snagu u javnom sektoru zdravstvenog sistema Republike Srbije.

\section{MATERIJAL I METODE RADA}

Retrospektivno su analizirani podaci o ljudskim resursima Instituta za javno zdravlje Srbije (IZJZS), baze podataka i publikacije Republičkog zavoda za statistiku, Republičkog fonda za razvoj, izveštaji Republičkog zavoda za tržište rada, kao i podaci o zdravstvenim rashodima dobijeni iz izveštaja Komore zdravstvenih ustanova (KZU). Komparativna analitička metoda je korišćena za procenu socioekonomskih indikatora i kretanja ljudskih resursa tokom petogodišnjeg perioda (2006-2010. godine). 


\section{REZULTATI}

Podaci pokazuju kako je svetska ekonomska kriza prekinula stabilan ekonomski rast u Srbiji. BDP po stanovniku u Srbiji u 2006. godini iznosio je 3.943 američka dolara (3.144 evra), da bi u 2008. godini, prema proceni Ministarstva finansija, dostigao 6.498 dolara (4.445 evra). U 2009. je počeo da se smanjuje na 5.499 dolara (3.955 evra), dok je u 2010. nastavio smanjenje i iznosio svega 5.006 dolara (3.781 evro). Do 2007. godine stopa rasta BDP bila je u intervalu od 3,6\% do 5,4\%, dok je u 2009 . godini zabeležen negativan rast od $-3,1 \%$. U 2010. godini imao je tendenciju laganog rasta od 1\% (Grafikon 1).

BDP Srbije po stanovniku, izražen preko kupovne moći, među najnižim je u Evropi i u 2010. godini bio je svega 35 indeksnih poena proseka Evropske Unije (EU) (Tabela 1). To je smanjenje za jedan procentni poen u odnosu na prethodnu 2009. godinu. Prema vrednostima indeksa ljudskog razvoja (HDI), Srbija zauzima 60. mesto u svetu, a 33. u Evropi. U periodu 2006-2010. godine nivo ljudskog razvoja u Srbiji porastao je za 2\%, očekivani životni vek za jednu godinu, dok su se prosečna i očekivana dužina školovanja povećale neznatno (Grafikon 2).

Izveštaj Ministarstva finansija za 2010. godinu uvodi i tri nova kompozitna indeksa: IHDI, koji predstavlja HDI prilagođen na osnovu nejednakosti u distribuciji dostignuća, GII, koji se odnosi na rodnu nejednakost, i MPI - indeks višedimenzionalnog siromaštva, koji prati usklađenost domaćinstava u oblasti obrazovanja, zdravstva i životnog standarda. Kod MPI uočen je izostanak značajne povezanosti ekonomskog razvoja zemlje i unapređenja u oblasti zdravstva i obrazovanja (Tabela 2).

U 2010. godini stopa ukupne inflacije bila je $10,3 \%$, što je znatno više u odnosu na prethodnu godinu, kada je bila 6,6\%. Tada je imala približan nivo kao inflacija u 2008. od 8,6\% i u 2007. od $11 \%$ (Grafikon 3). Prosečna inflacija je u istom periodu bila od 6,5\% u 2007. godini, $11,7 \%$ u 2008, 8,4\% u 2009. i $6,5 \%$ u 2010. godini. U poređenju sa zemljama iz okruženja, Srbija takođe ima znatno višu stopu prosečne inflacije (Tabela 3 ).

Tokom posmatranog petogodišnjeg perioda prosečne realne zarade beleže porast, sem u 2009. i 2010. godini, kada je registrovan njihov trend smanjenja (Grafikon 4). Prema podacima Ministarstva finansija, u 2009. prosečna realna zarada bila je 338 evra (469 dolara), a u 2010. godini 330 evra (439 dolara) (Tabela 4). Kada se uporede prosečne neto zarade u Srbiji sa zaradama u zdravstvenoj zaštiti i socijalnom radu u periodu 2006-2010. godine, može se uočiti da su zarade u zdravstvu bile značajno veće 2008. godine, da bi se gotovo izjednačile s prosečnim neto zaradama u Srbiji u 2010. godini (Grafikon 5).

Prosečna mesečna lična potrošnja po domaćinstvu u Srbiji u 2009. godini iznosila je 42.548 dinara, a u 2010. je smanjena na 42.448 dinara. Struktura lične potrošnje domaćinstava u 2009. godini je vrlo slična potrošnji u 2010. godini: najveće učešće u ukupnoj potrošnji imali su izdaci za ishranu (41,2\% u 2009, a $41,3 \%$ u 2010. godini), zatim troškovi stanovanja ( $16,1 \%$, odnosno 16\%), dok su se rashodi za zdravstvenu zaštitu sa 3,7\% u 2009. godini povećali na 4,1\% u 2010. godini (Tabela 5).

Iako su se rashodi domaćinstava za zdravstvenu zaštitu u 2010. godini povećali u odnosu na 2009. godinu, ukupna zdravstvena potrošnja po glavi stanovnika se ipak smanjila sa 673 dolara u 2008. na 546 dolara u 2010. godini (Tabela 6). U Srbiji je u 2010. godini $62 \%$ ukupnih rashoda za zdravstvo finansirano iz javnih izvora, stoga i najveći deo od strane Republičkog fon- da za zdravstveno osiguranje (RFZO). Deo javnog finansiranja zdravstvenih usluga obezbeđen je i preko Ministarstva zdravlja, preko regionalnih i lokalnih vlada, od strane Ministarstva odbrane, Ministarstva pravde i Vojnog zdravstvenog osiguranja (Grafikoni 6 i 7). Iz prethodnih grafikona se vidi da plaćanja RFZO većim delom određuju javno pružanje zdravstvenih usluga.

Prema podacima KZU, od 2006. do 2008. godine zabeleženo je stalno povećanje broja zaposlenih na neodređeno vreme u javnom sektoru zdravstva. U 2009. broj stalno zaposlenih se smanjio, da bi se neznatno povećao u 2010. godini (Tabela 7). Broj zaposlenih na određeno vreme je različit, a zavisi u velikoj meri od tipa zdravstvene ustanove i povećava broj ukupno zaposlenih u javnom zdravstvenom sektoru. Broj ukupno zaposlenih u zdravstvenom sektoru se takođe povećao u periodu 2006-2008. godine, dok se u 2009. i 2010. godini smanjio (Tabela 7). Najveći broj zaposlenih na određeno vreme bio je u Službi hitne medicinske pomoći (Tabela 8).

U strukturi ukupnog finansiranja javnog zdravstvenog sistema vidi se da najveći deo finansijskih sredstava odlazi na finansiranje zaposlenih u javnozdravstvenim ustanovama. Finansijska sredstva za zaposlene u javnom zdravstvu različito su raspoređena. Iz tabele 9 se vidi da se najveća finansijska sredstva usmeravaju za zaposlene u bolnicama.

Tokom 2009. i 2010. godine privredna aktivnost Srbije se smanjila, što je dovelo do porasta stope nezaposlenosti i usporavanja rasta zarada. Ukupan broj zaposlenih u 2010. godini smanjen je u odnosu na 2009. godinu za 4,66\%. Stopa nezaposlenosti se u 2009. godini povećala na $16,1 \%$, u odnosu na $13,6 \%$ u 2008. godini. U 2010. godini je sa blagim oporavkom privrednih aktivnosti očekivano i ublažavanje nezaposlenosti, ali ne samo da do toga nije došlo, nego se nezaposlenost povećala na 19,2\%, dok je zaposlenost smanjena za 4,9\% (Grafikon 8). Stopa nezaposlenosti u Srbiji i dalje je najveća u poređenju sa zemljama evrozone i zemljama u okruženju, osim Bosne i Hercegovine (Tabela 10). Stopa nezaposlenosti u javnom sektoru zdravstvene zaštite različita je za medicinske sestre i lekare u posmatranim godinama. Broj nezaposlenih medicinskih sestara je bio značajno veći u 2006. godini u poređenju sa 2010, ali je broj nezaposlenih lekara u 2010. bio više nego dvostruko veći u poređenju sa brojem nezaposlenih lekara u 2006. godini. U tabelama 11 i 12 prikazana je nezaposlenost u javnom sektoru zdravstvene zaštite.

\section{DISKUSIJA}

BDP u Srbiji je, prema definiciji, najvažniji makroekonomski agregat i merilo ukupne ekonomske aktivnosti svih domaćih institucionalnih jedinica. On obuhvata proizvodnju materijalnih dobara, kao i sve vrste usluga. Od 2006. do 2008. godine uočen je njegov rast, na koji su u posmatranom periodu pozitivno uticale strukturne reforme i ostvarene investicije, a najviše tražnja stanovništva, rast prodaje, zarade, penzije, krediti i uvoz [1]. BDP se 2009. smanjio pod uticajem pada domaće tražnje za oko 7\%, koja je prouzrokovana: smanjenjem stranog kapitala, usporavanjem kreditne aktivnosti, značajnim usporavanjem povećanja zarada (prema podacima Republičkog fonda za razvoj). U 2010. godini došlo je do blagog porasta BDP (od 1\%), koji je zasnovan na rastu izvozne tražnje i investicione potrošnje. U 2009. godini opšta ekonomska kriza je zaustavila relativno brz ekonomski 
razvoj u Srbiji. Kriza je uticala na niži nivo BDP po stanovniku u 2010. godini u visini od 5.006 američkih dolara (3.781 evra) u odnosu na 6.498 dolara (4.445 evra) u 2008. godini.

Svetska ekonomska kriza je uticala na sve zemlje. Posle decenije pozitivne stope rasta, sve zemlje Evrope, osim Poljske i Nemačke, zabeležile su u 2009. godini negativnu stopu rasta realnog BDP. Srbija, međutim, beleži manji pad BDP od proseka EU (-4.2\%) i većine evropskih i zemalja u regionu. Značajno veće smanjenje BDP zabeleženo je u mnogim evropskim zemljama: Estonija (-13.9\%), Irska (-7.6\%), Letonija (-18\%), Litvanija (-14.7\%), Mađarska (-6.7\% ), Rumunija (-7.1\%), Slovenija (-8.1\%), Finska (-8\%) i Island (-6.8\%) [2]. U poređenju sa zemljama iz regiona, samo je Makedonija napravila znatno manji pad BDP, od samo -0,7\%.

Javni dug Srbije u 2010. godini bio je 41,4\% BDP (pošto je manji od $80 \%$, prema kriterijumima Svetske banke, Srbija ne pripada kategoriji visoko zaduženih privrednih zemalja). Stranih direktnih investicija je od 2006. godine sve manje; u 2009. činile su 4,4\% BDP, a u 2010. godini 3\% BDP [3, 4]. Ukupna inflacija od 2009. godine predstavlja zvaničnu meru inflacije u Srbiji. Reč je o tzv. harmonizovanom indeksu cena, kao posebnom indeksu cena na malo, koji se obračunava po metodologiji usklađenoj s preporukama EU. To je promena cena fiksne korpe robe i usluga koju domaćinstva kupuju radi zadovoljavanja svojih potreba (lista proizvoda i usluga sadrži i finansijske usluge, usluge obrazovanja, osiguranja, ugostiteljske i zdravstvene usluge). Republički zavod za statistiku izračunao je vrednosti ovog indeksa tokom posmatranog perioda; uočeno je stalno smanjenje do 2010. godine, kada je vrednost počela da raste za čak 3,7\%. Istovremeno, Republički zavod za statistiku je prestao s izradom indeksa cena na malo, prema ranijoj metodologiji, pa su ti parametri neuporedivi u posmatranom periodu. Od 2006. do 2010. godine nivo prosečne inflacije u Srbiji bio je znatno viši u odnosu na prosek EU. Međutim, postoje i velike razlike u nivou inflacije između pojedinih zemalja. U poređenju sa zemljama iz okruženja (izuzev Rumunije), Srbija takođe ima znatno veću stopu inflacije $[5,6,7]$.

Svetska ekonomska kriza na kraju 2008. godine dovela je do destabilizacije deviznog tržišta, pa su morale da se primene mnoge antiinflatorne mere, kao što je mera „zamrzavanja” penzija i plata u javnom sektoru. Takođe je zaključen sporazum o ciljnoj inflaciji između Vlade Srbije i Narodne banke Srbije.

Pogoršanje makroekonomskih pokazatelja dovelo je do smanjenja životnog standarda stanovništva. Tokom posmatranog perioda uočena je fluktuacija stope rizika od siromaštva. U 2008. godini 580.000 ljudi živelo je ispod apsolutne linije siromaštva i imalo u proseku 7.937 dinara (97,5 evra; 142,5 dolara) po potrošačkoj jedinici mesečno, što daje stopu siromaštva od 7,9\%. U 2009. godini 652.218 stanovnika je živelo ispod apsolutne linije siromaštva, a u 2010. godini čak 670.812 stanovnika. Ekonomska kriza je 2010. godine prouzrokovala povećanje broja siromašnih građana, tako da je 9,2\% stanovništva živelo ispod apsolutne granice siromaštva sa prosečno 8,544 dinara (103 evra; 150 evra) mesečno. Stopa rizika od siromaštva je indikator socijalne isključenosti, koja nije izbor, već posledica nejednake raspodele nacionalnog bogatstva, loše socijalne solidarnosti, nejednakosti u pristupu mogućnostima i nedoslednosti u sprovođenju deklarisanih opštih i evropskih obaveza i standarda. Stopa rizika od siromaštva u EU u 2008. godini bila je 16,5\%, u Sloveniji 12,3\%, a u Srbiji, prema izveštajima Republičkog fonda za razvoj, 20,6\%. Srbija ima visok rizik od siromaštva, gde su najosetljivije starije osobe i deca mlađa od 15 godina.

Tokom posmatranog perioda indeks ljudskog razvoja (HDI), indikator kvaliteta života i međuzavisnosti ekonomskog i socijalnog razvoja, koji izražava prosečna dostignuća zemlje u oblasti zdravstva, obrazovanja i životnog standarda, meren veličinom BDP po stanovniku po kupovnoj moći, povećavao se. Značajan porast HDI u 2010. godini $(0,735)$ rezultat je povećanja očekivanog trajanja života i povećanja indeksa kupovne moći građana. U poređenju sa zemljama u regionu, u 2007. godini uočava se da su Albanija (0,719), Makedonija $(0,701)$ i Bosna i Hercegovina $(0,710)$ imale manje vrednosti HDI, dok je Slovenija imala visoku vrednost $\operatorname{HDI}(0,929)$ [8].

Rashodi za zdravstvenu zaštitu su se od 2006. do 2010. godine stalno povećavali, kako u svom ukupnom iznosu, tako i za svaku od ispitivanih komponenti: rashodi zavoda za zdravstveno osiguranje, javne finansije i rashodi privatnog sektora za zdravstvenu zaštitu. Gledajući potrošnju za zdravstvenu zaštitu kao procenat BDP, Srbija je sa 10,4\% iznad proseka EU (9\% u 2008), a približno na nivou Austrije, Nemačke, Portugala, Švajcarske, Bosne i Hercegovine [9]. Rashodi za zdravstvenu zaštitu u Srbiji su značajno veći nego u Bugarskoj, Češkoj, Estoniji, Španiji, Kipru, Litvaniji, Luksemburgu, Mađarskoj, Poljskoj, Rumuniji, Sloveniji i Švedskoj.

U 2009. godini Vlada Republike Srbije je sprovela restriktivnu fiskalnu politiku, što je uključivalo zamrzavanje plata i penzija u javnom sektoru i smanjenje javne potrošnje. Tokom celog perioda, s izuzetkom 2008. godine, prosečni realni rast zarada bio je znatno veći od rasta ukupne privredne aktivnosti i proizvodnje. U poređenju sa susednim zemljama, neto zarada od 338 evra u Srbiji u 2009. godini bila je veća nego u Bugarskoj i Albaniji, ali manja nego u Bosni i Hercegovini (410 evra), Mađarskoj (458 evra), Hrvatskoj (737 evra) i Sloveniji (930 evra). Na približno istom nivou su kao i u Srbiji neto zarade u Rumuniji i Makedoniji [9].

Zarade zaposlenih u javnozdravstvenim ustanovama je tokom posmatranog perioda skoro potpuno finansirao RFZO. Finansiranje zdravstvenih ustanova koje su u sistemu javne zdravstvene zaštite zasnovano je na podacima o broju zaposlenih, a zarade zaposlenih imaju daleko najveći udeo u ukupnim troškovima u službi zdravstvene zaštite. Povećanje troškova za zaposlene u zdravstvenom sektoru u periodu 2006-2010. godine pokazuje sporije povećanje ukupnih zarada zaposlenih od povećanja ukupnih rashoda, što je komplementarno s planiranim smanjenjem rashoda za zaposlene od strane RFZO. Prihodi RFZO od 2006. do 2010. godine povećani su ukupno 65\%, dok su bruto zarade povećane ukupno $60 \%$. Upoređujući podatke o prihodima RFZO i zaradama radnika zdravstvene zaštite u 2008. godini s podacima za 2010. godinu, može se uočiti da je udeo rashoda za zaposlene u ukupnim tekućim rashodima smanjen sa $61,20 \%$ u 2008. na 56,21\% u 2010. godini [10].

Prema podacima KZU iz 2010. godine, naknade za zaposlene u javnom zdravstvenom sektoru u 2009. godini zabeležile su nominalno povećanje od 3,16\%. Troškovi života u 2009. godini u proseku su povećani za $8,6 \%$ u odnosu na prosek prethodne godine. Drugim rečima, u odnosu na prethodnu godinu, troškovi za zaposlene u javnozdravstvenom sektoru su realno manji za 5,1\%.

Nezaposlenost u Srbiji je veliki ekonomski i socijalni problem nasleđen od pre tranzicije, koja je dodatno produbila problem 
kroz proces svojinske transformacije, restrukturiranja preduzeća i krize u 2009. i 2010. godini. Tržište rada u Srbiji razlikuje se po pripadnosti javnom ili privatnom sektoru, pa tako javni službenici imaju visoku sigurnost posla, dok se u privatnom sektoru odgovor na krizu ogleda u smanjenju broja zaposlenih. Stopa nezaposlenosti u Srbiji u 2010. godini dostigla je $19,2 \%$. U 2009. bila je 16,6\%, dok je u istoj godini prosečna stopa nezaposlenosti u 27 zemalja EU bila 9,3\%, a u evrozoni 9,8\% $[5,6,7]$. Najniža stopa nezaposlenosti je zabeležena u Norveškoj (3,2\%). Situaciju na tržištu rada dodatno komplikuje činjenica da je 65,5\% od ukupnog broja nezaposlenih u 2009. godini u kategoriji dugoročno nezaposlenih (lica koja čekaju na zaposlenje duže od godinu dana). To ukazuje na izuzetno visok stepen socijalne isključenosti. U 2009. visina dugoročne stope nezaposlenosti u Srbiji, u poređenju sa EU, zemljama evrozone i svim zemljama u regionu (u EU 33,7\%, u Sloveniji 27,5\%) značajno je veća $(65,5 \%)$. Veoma dugoročna stopa nezaposlenosti $(8,1 \%)$ izuzetno je visoka u odnosu na prosek EU i susednih zemalja (EU 1,5\%, Slovenija 0,9\%). Značajno višu stopu u odnosu na EU pokazuje stopa nezaposlenosti među ženama u Srbiji (18,4\%). U zemljama EU prosečna stopa nezaposlenih žena je dva puta niža i na nivou je od 9,1\%, dok je u Sloveniji 2009. godine bila $6,4 \%$. Srbija sa $42,5 \%$ stope nezaposlenosti mladih ima daleko veću stopu nezaposlenosti osoba uzrasta 15-24 godine nego što je prosek stope mladih koji ne rade u EU $(21,4 \%)$ i Sloveniji (15,7\%). Stopa zaposlenosti u Srbiji od 60,5\% je najniža u poređenju s EU i zemljama u okruženju. Prosečna stopa zaposlenosti u EU i Sloveniji u 2009. godini bila je 71,3\%. Stopa zaposlenosti radno sposobnog stanovništva u Srbiji bila je značajno niža (50\%) u odnosu na prosečnu stopu zaposlenosti u EU $(64,8 \%)$ u 2009. godini. Stopa nezaposlenosti u javnom zdravstvenom sektoru beleži smanjenje broja nezaposlenih medicinskih sestara i naglo povećanje broja nezaposlenih lekara u okviru posmatranog perioda od pet godina. Broj nezaposlenih medicinskih sestara bio je značajno veći u 2006. u poređenju sa 2010. godinom (7109 prema 4623) [11]. Struktura nezaposlenih je bila slična, osim za kategoriju nezaposlenih mladih i nezaposlenih mladih žena, koja je imala manju stopu 2010. godine - $40,17 \%$ i $35,78 \%$, u poređenju sa 2006 , kada je nezaposlenost mladih do 25 godina bila $48,09 \%$, a žena do 25 godina $43,49 \%$. Broj nezaposlenih lekara u 2010. godini je dvostruko veći u poređenju sa brojem nezaposlenih u 2006, ali s manjim procentom nezaposlenih mladih i onih koji su čekali više od godinu dana. Očigledno je da su ekonomska kretanja u Srbiji uticala na stopu nezaposlenosti u javnom zdravstvenom sektoru, na način gde su lekari podlegli većem uticaju krize i više osetili mere koje su uticale na smanjenje rashoda za zaposlene $u$ javnom sektoru zdravstvene zaštite.

Problemi s finansiranjem javnog sektora zdravstva su zabeleženi i u drugim zemljama u tranziciji, kao što su Kirgistan, Tadžikistan, Kazahstan i Letonija [12].

S obzirom na to da se na zaposlene u javnom sektoru zdravstva izdvajaju najveća finansijska sredstva, problemi njihovog finansiranja postoje i u drugim državama [13], osim u visokorazvijenim zemljama, koje se susreću s problemom nedostatka lekara i ostalog visokoobrazovanog medicinskog kadra. Brojne studije su se bavile upravo tim problemom [14].

\section{ZAKLJUČAK}

Na osnovu dobijenih rezultata može se zaključiti da je svetska ekonomska kriza loše uticala ne samo na stopu rasta BDP, inflaciju i nezaposlenost, nego i na radnu snagu u javnozdravstvenom sektoru u Republici Srbiji, na zarade zaposlenih, ali i na strukturu nezaposlenih lica. 